\title{
Tekstilatkritumu utilizēšana un reciklēšana
}

\author{
Inese Ziemele ${ }^{1}$, Ilze Kovaļevska², Dana Beļakova ${ }^{3}$, Iveta Ābele ${ }^{4}$ \\ ${ }^{1-4}$ Dizaina tehnoloğiju institūts, Materiālzinātnes un lietišksās ķı̄imijas fakultāte, Rīgas Tehniskā universitāte
}

\begin{abstract}
Kopsavilkums. Rakstā atspoguḷotas spēkā esošās atkritumu apsaimniekošanas prasības. Aprakstîtas tekstilatkritumu utilizēšanas un reciklēšanas metodes un to realizēšanas iespējas Latvijā, Baltijā un Eiropā. Noskaidrots otrreiz lietojamo tekstilmateriālu šķiedru sastāvs, kuru īpašības atbilst un kuras ir ekonomiski izdevīgi izmantot atkārtotā pārstrādes procesā jaunu produktu iegūšanai. Izstrādāti ieteikumi tekstilizstrādājumu ražotājiem atkritumu reciklēšanai un utilizēšanai Latvijā.
\end{abstract}

Atslēgas vārdi: Tekstilatkritumi, atkritumu apsaimniekošana, tekstilizstrādājumu reciklēšana, utilizēšana.

\section{IEVADS}

Līdztekus citām ikdienas precēm, strauji pieaug arī izlietoto tekstiliju apjomi. Turklāt, ne mazums atkritumu rodas Latvijas tekstilizstrādājumu ražošanas un pārstrādes uzņēmumos. Tekstilatkritumu apsaimniekošanai Latvijā joprojām nav izveidota valstiski vienota sistēma un potenciāli lietderīgus materiālus apglabā atkritumu poligonos. Viens no galvenajiem atkritumu poligonu un $\mathrm{CO}_{2}$ gāzes izmešu daudzuma samazināšanas un reciklēto un utilizēto tekstilatkritumu daudzuma palielināšanas principiem Latvijā ir: "Piesārṇotājs maksā par piesārņojumu". Tas liek apglabāšanas un dedzināšanas vietā meklēt citus atkritumu apsaimniekošanas pañēmienus, kas Latvijas iedzīvotājiem un uzņēmumiem izmaksā ar katru gadu arvien vairāk. Šobrīd aktuāli izstrādāt ieteikumus, kā racionāli apsaimniekot tekstila atkritumus, lai samazinātu atkritumu apsaimniekošanas izmaksas un saglabātu dabas resursus.

\section{VIDES TIESĪBU AKTI}

1992. gada jūnijā Riodežaneiro norisinājās Apvienoto Nāciju Organizācijas (ANO) konference "Par vidi un attīstību". Šajā konferencē piedalījās 179 valstu vadītāji. Šis apstāklis to padarīja par vienu no nozīmīgākajiem pasākumiem vides aizsardzības jomā pasaulē. Konferences galvenā tēma bija siltumnīcas efektu izraisošo gāzu daudzuma stabilizācija atmosfērā, tādejādi saglabājot pasaules klimata sistēmu (1).

Riodežaneiro deklarācijas "Par vidi un attīstību" ietvaros tika izvirzīi 27 principi, kas ANO dalībvalstīm jāievēro, sastādot vides aizsardzības plānus, kā arī citus tiesību aktus, kas saistīti ar vides apsaimniekošanu. Deklarācijā īpaši uzsvērtas cilvēka tiesības - dzīvot harmonijā ar dabu. Daži no svarīgākajiem izvirzītajiem principiem paredz:

- tiesības izmantot savus dabas resursus saskan̄ā ar vides un attīstības politiku, nenodarot kaitējumu videi, un citu valstu teritorijām;

- attīstībai jābūt saskaṇā ar nākamo paaudžu interesēm;

- jāsamazina vai jānovērš neilgtspējīga ražošana;

- jāinformē iedzīvotāji un jāveicina to līdzdalība vides aizsardzībā;
- jāievieš efektīvi vides tiesību akti;

- jāizstrādā valsts likumi par atbildību un kompensāciju tiem, kuri cietuši no vides piesārņojuma;

- jāveicina vides aizsardzība, izmantojot ekonomiskos instrumentus, pēc principa - piesārņotājs maksā par piesārņojumu (2).

Spēkā esošajā Eiropas direktīvā 008/89/EK ir izvirzītas atkritumu rašanās un novēršanas prasības, paredzot ES dalībvalstīs palielināt reciklēto atkritumu daudzumu vismaz par $50 \%$ laika posmā no direktīvas spēkā stāšanās brīža no 2008. gada līdz 2020. gadam (3). Šìs programmas ietvaros ES dalībvalstīm jāveido atkritumu apsaimniekošanas plāns vai atkritumu novēršanas programma, regulāri jāinformē un jāizglīto sabiedrība, kā arī jāveicina atkritumu pārstrāde (4).

\section{CIETO SADZ̄̄VES UN NEBĪSTAMO ATKRITUMU APSAIMNIEKOŠANA LATVIJĀ}

2012. gada Eurostat dati par cieto atkritumu daudzumu Eiropā liecina, ka tajā gadā Latvijā atkritumos nonāca 2,21 miljons t cieto sadz̄ives un rūpniecisko atkritumu. 1. attēlā redzams atkritumu apjoma sadalījums pa to veidiem (5). Latvijā atkritumu apsaimniekošanu regulē vairāk nekā 40 normatīvie akti, piemēram, Atkritumu apsaimniekošanas likums, Likums par sabiedrisko pakalpojumu regulatoriem, Likums par pašvaldībām, Dabas resursu nodokḷa likums u.c. (6).

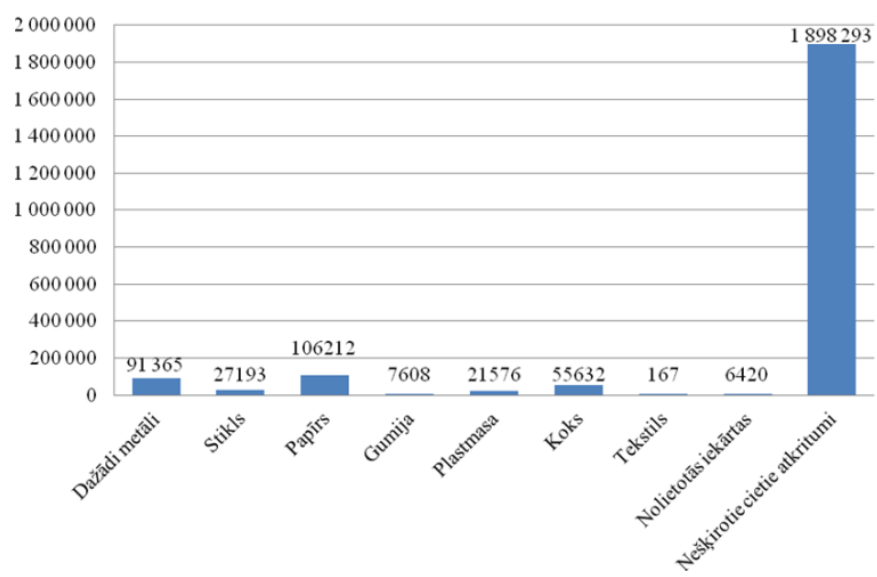

1. att. Cieto atkritumu daudzums (tā) Latvijā 2012. gadā (5).

Periodā no 2006. gada līdz 2012. gadam valsts atkritumu apsaimniekošanas plāna ietvaros, vienojoties pašvaldībām, kā arī, analizējot ekonomiskos aspektus, izveidoti 10 Latvijas atkritumu apsaimniekošanas reǵioni. Atkritumi, kas rodas pašvaldību administratīvajās teritorijās, tiek apglabāti tikai attiecīgajā atkritumu apsaimniekošanas reǵionā. Vislielākais ir Ziemel̦vidzemes reǵions, kurā ietilpst Valmiera un 21 novads, savukārt vismazākais ir Ventspils reǵions, kurā ietipst Ventspils un 3 novadi (7). 


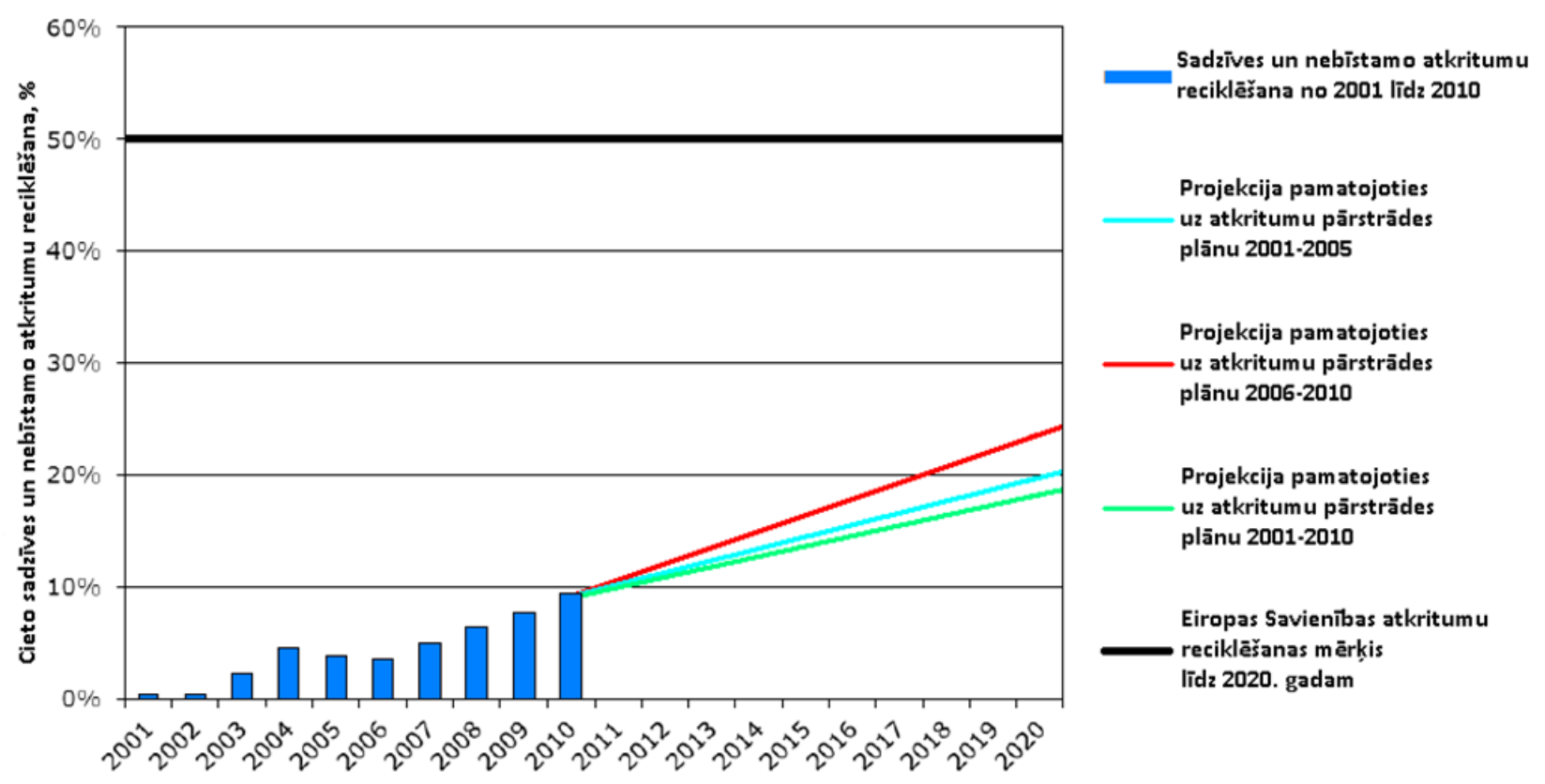

2. att. Cieto sadzīves un nebīstamo atkritumu reciklēšana Latvijā (8).

Latvijā kopš deviṇdesmito gadu beigām ir ievērojami samazinājies atkritumu apglabāšanas poligonu skaits. 1998. gadā atkritumu izgāztuvju skaits bija 558; 2006. gadā tas samazinājās līdz 99 (9). Savukārt 2010. gadā darbojās 24 sadzīves "nebīstamo" un 4 bīstamo atkritumu poligoni - par 12 mazāk nekā 2009. gadā (10).

Latvijas 2013.-2020. gada „Atkritumu apsaimniekošanas valsts plānā" minēts, ka atbalstāmie atkritumu apsaimniekošanas pasākumi ir atkritumu rašanās novēršana, šķirošana, pārstrāde. Savukārt jaunu poligonu izveide netiks atbalstīta (6).

Ievērojot līdzšinējos Latvijas panākumus un tālākos atkritumu reǵenerācijas plānus, paredzams, ka līdz 2020. gadam atkritumu daudzums, kas nonāk poligonos samazināsies tikai par aptuveni $20 \%$ (sk. 2. attēlu). Tas nozīmē, ka Latvija neizpild̄̄s Eiropas parlamenta un padomes atkritumu apsaimniekošanas mērḳi uz pusi samazināt apglabājamo atkritumu daudzumu (3).

\section{TEKSTILATKRITUMI LATVIJĀ}

Šobrīd Latvijā reǵistrēts vairāk nekā 1400 tekstilizstrādājumu ražošanas uzṇēmumu, pārsvarā tie ir mazi vai vidēji uzņēmumi (11).

Līdzīgi kā jebkurā citā ražošanā, arī tekstilizstrādājumu ražošanas procesā rodas ražošanas atkritumi. Piemēram, šūšanas uzṇēmumos tie ir detaļu piegriešanas procesa atkritumi, kur to daudzums atkarīgs no ražoto izstrādājumu veida, drānu klāšanas piegriešanas iekārtu veida (manuāla vai automātiska), detaļu izvietojumu efektivitātes u.c. faktoriem.

Saskan̄ā ar Centrālās statistikas pārvaldes datiem arī patērētais apgèerbu daudzums valstī nosacīti ir palielinājies, jo palielinājušies izdevumi tā iegādei no 73,09 EUR uz vienu mājsaimniecības locekli 2002. gadā līdz 149,16 EUR 2013. gadā (11). Jo lielāks ir mājsaimniecības tekstilizstrādājumu patēriņšs, jo vairāk tekstilatkritumu rodas. Noteikt tekstilatkritumu daudzumu mājsaimniecībās ir sarežğīti, bet galvenie faktori, kas ietekmē patērētāju vēlmi atbrīvoties no tekstilizstrādājumiem, ir nolietojums, modes tendenču aktualitāte, izmēru neatbilstība (apgēerbiem), stila maiņa, darba vietas maiṇa (apgeērbiem), ekonomiskās situācijas uzlabošanās u.c.

Tekstilatkritumus rada patērētāju sabiedrība, kas pieradusi pie ērtībām, liela produktu apgrozījuma un straujas modes tendenču maiņas. Uzņēmumu ražotie izstrādājumi bieži nav paredzēti ilgstošai lietošanai, bet patērētāji nav ieinteresēti to labošanā, jo jauna izstrādājuma iegāde bieži vien ir izdevīgāka, ērtāka un lētāka nekā vecā atjaunošana. Cilvēkiem trūkst informācijas par tekstilizstrādājumu rūpniecības un tekstilatkritumu ietekmi uz dabu. Tekstila izstrādājumu ražošanas procesā tiek patērēti energoresursi, gaiss, zeme. Ūdens tiek piesārņots ar kaitīgajiem izmešiem, kas rodas, piemēram, izstrādājumu krāsošanas procesā. Tomēr lielāko kaitējumu videi rada apglabātie tekstilatkritumi. To sadalī̌sanās ilgums ir līdz pat 200 gadiem, un sadaloties tie piesārņo augsni, gaisu un ūdeni.

Pēc Eirostat datiem 2012. gadā Latvijā tika savāktas 167 t tekstilatkritumu (5). Dati attiecas tikai uz ş̧̧irotajiem tekstilizstrādājumiem. Lielākā dal̦a tekstilatkritumu joprojām nonāk atkritumu poligons.

\section{V.TEKSTILIZSTRĀDĀJUMU OTRREIZĒJĀA PĀRSTRĀDE}

Gandrīz visus tekstilatkritumus iespējams reciklēt. Tekstilizstrādājumu reciklēšana ir ieguvums labdarības organizācijām. Atbalstot šīs organizācijas, iespējams samazināt cieto atkritumu daudzumu, radot jaunas darba vietas un uzlabojot vides stāvokli.

Tā kā tekstilizstrādājumi ir viegli reciklējami, to pārstrāde ir ne tikai nepieciešama, bet arī obligāta, lai samazinātu tekstilmateriālu daudzumu atkritumu poligonos. Šobrīd daudzās Eiropas valstīs un arī citur pasaulē tiek attīstīti tekstilizstrādājumu reciklēšanas uzṇēmumi, un to darbība ir ne 
vien draudzīga videi, bet arī ekonomiski izdevīga. Pēc EuroPages datiem (12) Eiropā reǵistrēti vairāk nekā 300 tekstilmateriālu reciklēšanas un šķirošanas uzṇēmi (3. attēls).

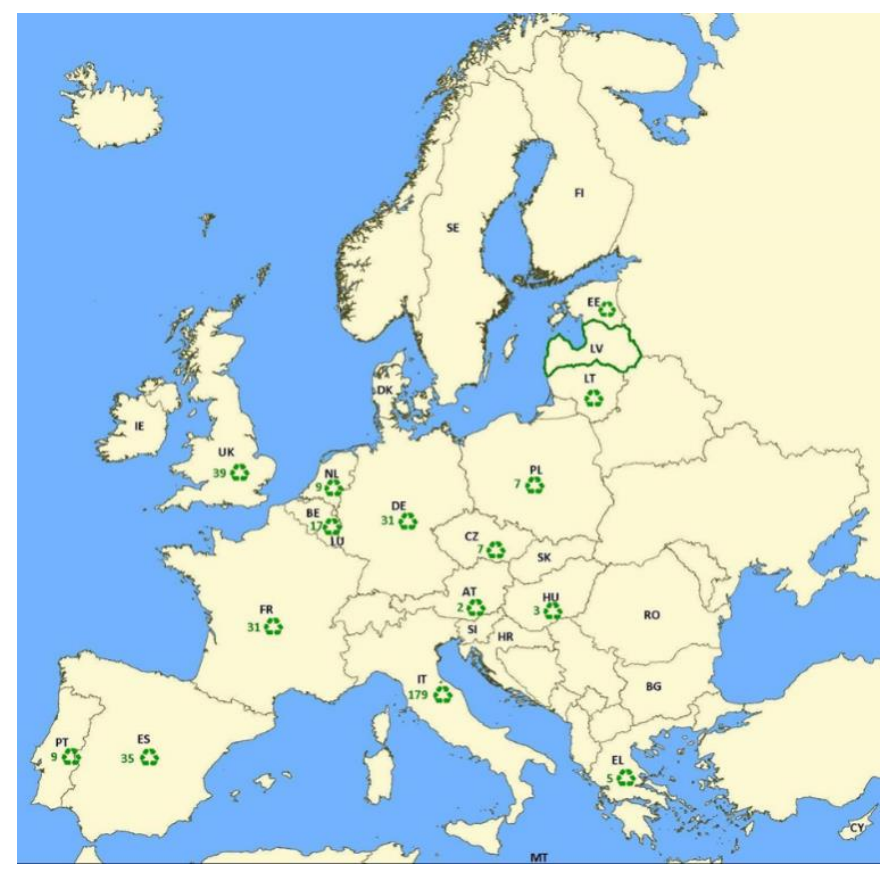

3. att. Tekstilmateriālu reciklēšanas uzṇēmumi Eiropas Savienības dalībvalstīs (12).

Lielākās tekstilizstrādājumu reciklēšanas valstis ir tās, kurās visplašāk attīstīta apǵērbu patēēēăana un ražošana - Francija, Lielbritānija, Itālija. Eiropas Savienības dalībvalstīs tiek attīstìta tekstilatkritumu dalītā šķirošana, kas labvēlīgi ietekmē pārstrādes uzn̄ēmumu attīstību. Tekstilatkritumu reciklēšanas veicināšanai, atkritumus, tāpat kā gatavos produktus, eksportē un importē uz valstīm, kur pieejami pārstrādes uzṇēmumi vai arī citas tekstilatkritumu utilizēšanas iespējas. Piemēram, Lielbritānijā radušos tekstilatkritumu daudzums gadā ir apmēram 2,35 miljoni t, tas ir, apmēram $40 \mathrm{~kg}$ (ieskaitot tekstiliju ražošanas atkritumus) uz vienu iedzīvotāju. Apmēram 13 \% no saražotajiem tekstilatkritumiem savāc, šķiro un nosūta uz Austrumeiropu un Āfriku, kur vietējie tirgotāji tos pārdod lietoto preču veikalos (13).

\section{A. Mājsaimniecībā lietoto tekstilizstrādājumu utilizēšana}

Dažādām tekstilizstrādājumiem piemērojamas dažādas pārstrādes metodes. Viens no izplatītākajiem reciklēšanas veidiem ir labdarība. Tekstilizstrādājumus ziedo labdarības organizācijām, kur tos šķiro pēc kvalitātes, sezonalitātes, kā arī pielietojuma. Labdarības organizācijas ar šiem apǵērbiem, apaviem, mājsaimniecības tekstilizstrādājumiem, kā arī citiem sadz̄ivē un ikdienā lietojamiem priekšmetiem apgādā maznodrošinātos, bērnu namus, cietumus, dabas katastrofu postītos pasaules reǵionus utt. Šādi var pārstrādāt gatavos tekstilizstrādājumus - apǵērbu, segas, galdautus, paklājus u.c. mājsaimniecības tekstilizstrādājumus. Svarīga ir izstrādājuma kvalitāte un nolietojums, nevis materiāla šķiedru sastāvs.

Tekstilizstrādājumu otrreizējā pārstrāde notiek arī pateicoties mazumtirdzniecības uzṇēmumu jeb lietoto preču veikalu darbībai. Lietotās preces atkārtotā pārdošanā veikalu plauktos nonāk, pateicoties atkritumu šķirošanas uzṇēmumiem, kuri nodrošina pilsētas ar atkritumu šķirošanas konteineriem. Šāda prakse ir Lielbritānijā, Francijā, Vācijā u.c. valstīs. Šajās valstīs savāktie lietotie tekstilizstrādājumi nonāk šķirošanas uzṇēmumos, kur tās šksiro pēc kvalitātes, nolietojuma pakāpes, sezonalitātes un pielietojuma. Izstrādājumus pako dažādu izmēru polietilēna iepakojumos un nosūta pie pasūtītāja. Tekstilpreču iepakojuma cenu lielākoties nosaka pēc svara, tomēr cena var mainīties arī atkarībā no iepakojuma satura. Pārdodot lietotos tekstilizstrādājumus, svarīgi ievērot izstrādājumu kvalitāti un nolietojuma pakāpi.

Tekstilizstrādājumi pārstrāde jaunos izstrādājumos ir arī to pārveide jeb pāršǔšana jaunās lietās. Beidzoties tekstilizstrādājuma valkmūžam, pasliktinoties tā kvalitātes rādītājiem vai arī tam kḷūstot morāli vecam, izstrādājumu iespējams pārveidot citā jaunā lietā, piemēram, citā apgeērbā (22), aksesuārā, mājas tekstilizstrādājumā - spilvenā, paklājā, bērnu rotallietā u.c. (20).

\section{B. Tekstilatkritumu mehāniskā, termiskā un ķ̄imiskā pārstrāde un utilizācija sadedzinot}

Tekstilmateriāli, kurus nav iespējams utilizēt pārdodot vai ziedojot, ir lietderīgi izejmateriāli, un tos pakḷauj mehāniskai, termiskai un ķīmiskai reciklēšanai un utilizācijai, sadedzinot enerğijas un situma ieguvei.

Tekstilmateriālus, kuru sastāvā ir dažādi šksiedrmateriāli, ir grūti pārstrādāt, jo grūti atdalīt šķiedras pēc to sastāva. Šajā gadījumā izmantojama mehāniska pārstrāde. Šim pārstrādes veidam pakḷauj tekstilmateriālus, kas vairs nav izmantojami. Pārstrāde notiek sasmalcinot tekstilmateriālus līdz šksiedru elementiem, no kuriem tālāk ražo piln̄̄gi jaunus produktus, piemēram, siltumizolācijas materiālus, spilvenu pildījumus, matračus, paklājus utt.

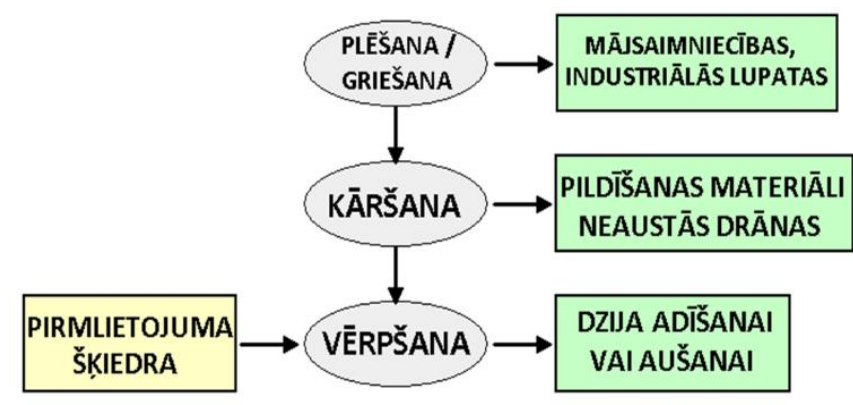

4. att. Tekstilmateriālu mehāniskās pārstrādes shēma (14).

4. attēlā parādīts, kā mehāniski pārstrādā tekstilatkritumus. Tekstilatkritumus var sagriezt lupatās, tādejādi tos atkārtoti var izmantot, piemēram, automazgātavās, un var sasmalcināt līdz stāvoklim, ka tie vizuāli atgādina šķiedras. Tālākajā pārstrādes procesā šķiedras kārš, atdala no tām sīkās šķiedras, netīrumus un gružus. Kārstās šķiedras var izmantot kā pildīšanas materiālu vai arī neausto drānu ražošanā. Kārstajām reciklētajām šķiedrām, pievienojot pirmlietojuma šķiedras jeb jaunas šķiedras, vērpj dziju, no kuras tālāk ražo austās vai adītās drānas. 
Piemēram, kokvilnas materiālus, tā kā tie labi absorbē mitrumu, var sadalīt industriālajās lupatās vai arī pārstrādāt škiedrās, mehāniski samaļot speciālās iekārtās. Pēc materiāla sasmacināšanas tas vizuāli ir l,oti līdzīgs neapstrādātai kokvilnai, tomēr atsevišķ reciklēto šķiedru pavedieni ir garāki, bet citi īsāki nekā pirmlietojuma kokvilnas šķiedras. Tāpēc, lai reciklētās škiiedras būtu izturīgākas, tām pievieno poliestera (PES) šķiedras un vērpj dzijā (90\% kokvilnas un $10 \%$ PES), (15). No pārstrādātās kokvilnas ražo dažādus tekstilizstrādājumus (5. attēls).

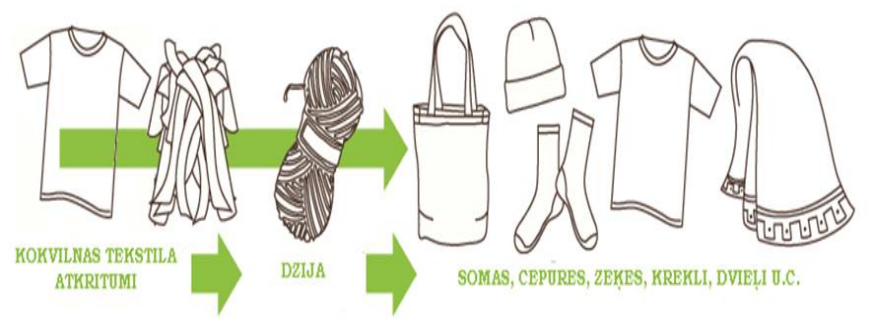

5. att. Kokvilnas izstrādājumu reciklēšana (16).

Kokvilnas tekstilatkritumus un arī citus dabisko šķiedru materiālus var pārstrādāt pap̄īā, ko lieto arī naudaszīmju ražošanā.

Sintētiskos materiālus, piemēram, poliesteru, poliamīdu un polipropilēnu pārstrādā termiski, tos kausējot. No tiem ražo plastmasas izstrādājumus (kastes, spainus, pogas, caurules utt.).

Poliamīdu iespējams pārstrādāt poliamīda šķiedras aglomerātā (6. attēls), ko izmanto plastmasas ražošanai. Poliamīda atkritumi ir vērtīgs izejvielu resurss, un to tirgus cena ir diezgan augsta.

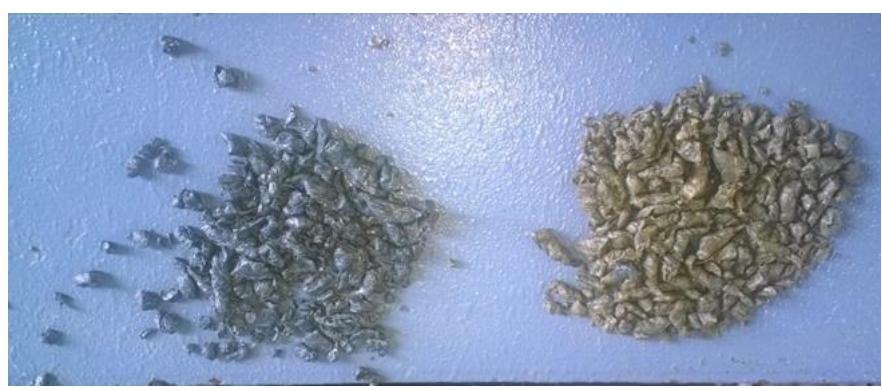

6. att. Poliamīda šķiedru aglomerāts (autora attēls uzṇēmumā Antriteksa, Lietuva).

Sintētiskajām šķiedrām piemērota ar̄̄ atkritumu ķīmiskā pārstrāde, kas l̦auj pilnībā reciklēt sintētiskos materiālus, tomēr procesam nepieciešamas specifiskas, l̦oti dārgas iekārtas. 7. attēlā shematiski parādīta poliestera pārstrāde - poliestera tekstilatkritumus mehāniski sasmalcina, tad pakḷauj k̦īmiskai pārstrādei un rezultātā iegūst polietilēna (PET) granulas. No granulām ražo poliestera štāpel̦šksiedras un dzijas pavedienus. Poliestera tekstilmateriālus ķīmiskās pārstrādes rezultātā iegūst jaunus reciklēta poliestera izstrādājumus.

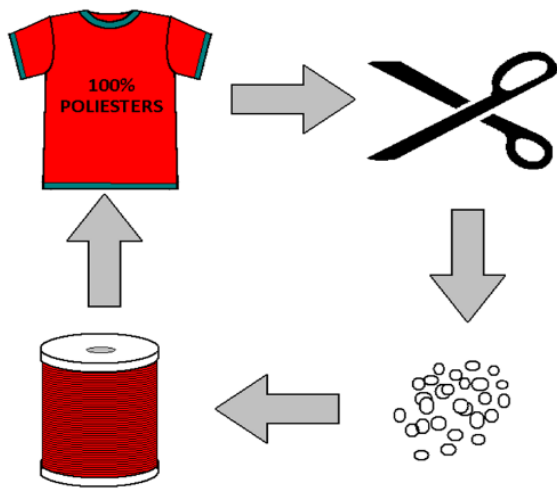

7. att. Poliestera pārstrāde

Raugoties no vides aizsardzības viedokḷa, tekstilatkritumu sadedzināšana nav droša, jo tekstilatkritumu un citu cieto sadzīves atkritumu sadedzināšana var radīt bīstamu gaisa piesārṇojumu (17). Atkritumu sadedzināšanas iekārtu darbības princips parādīts 8. attēlā. Tekstilatkritumu s piegādā sadedzināšanas uzñēmumam, un ar atkritumu padeves krānu tekstilmateriālus padod uz dedzināšanas katlu. No dedzināšanas katla izdalās tvaiks, kuru pārstrādā siltumenerğijā un elektroenerǵijāa Dūmgāzes un pelnu putekḷus novirza uz filtrēšanas sistēmu, uzkrāj un likvidē, apglabājot atkritumu poligonos. Savukārt dūmgāzes un tvaiku, kas rodas pēc apstrādes filtru sistēmā, izvada gaisā.

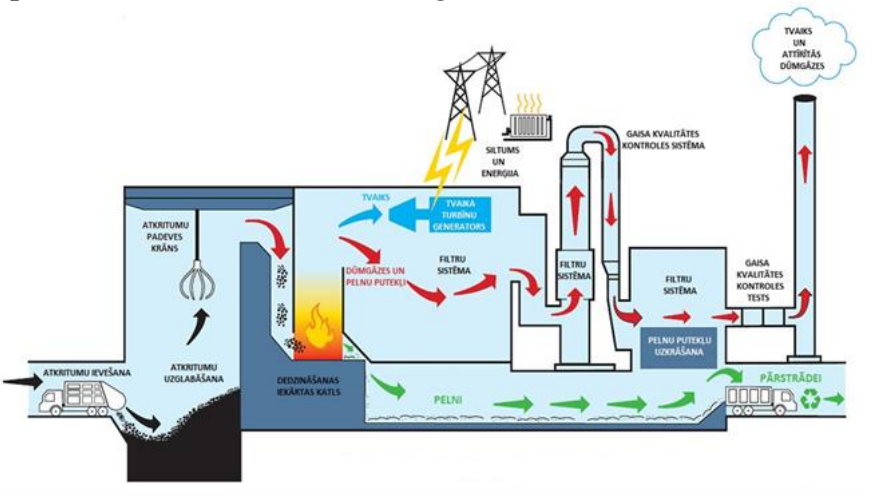

8. att. Atkritumu sadedzināšanas iekārtu darbības princips (18).

Atkritumu utilizācija sadedzinot, ja iegūst enerǵiju, samazina atkritumu daudzumu poligonos un ir pozitīva atkritumu pārstrādes alternatīva.

\section{APĢĒRBA UTILIZĀCIJAS UN RECIKLĒĚSNAS IESPĒJAS LATVIJĀ}

Rīgā kopš 2009. gada darbojas sociālais uzṇēmums Otrā Elpa, kuram ir labdarības veikali. Šobrīd atvērti jau divi veikali Rīgā un viens veikals Liepājā. Uzṇēmums saṇem ziedojumus no privātpersonām un dažādām organizācijām. Šajos veikalos var ziedot apǵērbu, apavus, grāmatas u.c. sadzīves priekšmetus, tādejādi novēršot nevajadzīgo lietu izmešanu atkritumu konteineros un to tālāko nonākšanu poligonos. Veikalos veic saņemto ziedojumu šksirošanu pēc sezonalitātes, kvalitātes, kā arī pēc pielietojuma. Atsevišksas lietas tiek atstātas pārdošanai veikalā, bet lielākā daḷa tiek ziedota dažādām organizācijām, piemēram, bērnu namiem, maznodrošinātajiem, cietumiem utt. 
2014. gadā no privātpersonām tika saņemtas 155671 apǵērbu vienības, kas ir par 77602 apgeērbu vienībām vairāk nekā 2013. gadā (19).

Daļu no lietošanai nederīgajām tekstilizstrādājumiem ziedo māksliniekiem, kas tos reciklē jaunos izstrādājumos. Tekstilizstrādājumus, kurus nogādā sociālajām organizācijām, dala pēc pieprasījuma. SIA $Z 2 B$ aušanas studija $L U D E$ (20) savu darbību uzsāka 2013. gadā. Uzṇēmumā auž paklājus, kuru izejmateriāli ir tekstilmateriālu atkritumi no ražošanas uzñēmumiem vai ziedotie lietotie apǵērbi. Šobrīd uzṇēmums nodarbina 5 darbiniekus un vidējais ražoto paklāju daudzums ir 10 vienības mēnes̄i. Viena paklāja (9. attēls) masa ir aptuveni $2 \mathrm{~kg}$ un uzñēmuma divu gadu darbības laikā ir pārstrādāti vairāk nekā $300 \mathrm{~kg}$ tekstilatkritumu.

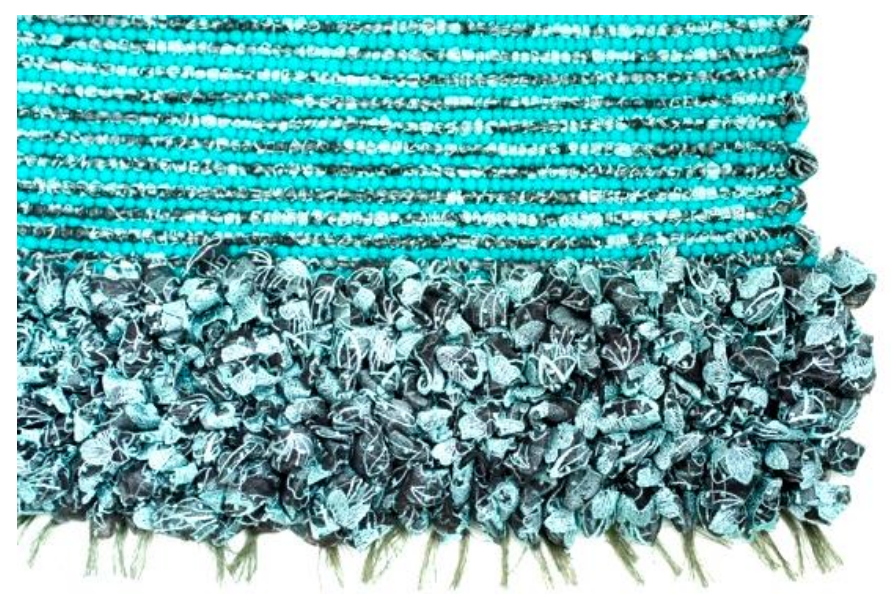

9. att. Aušanas studijas LUDE kolekcijas Lude Lace austais paklājs Turquoise Dream (20).

Uzṇēmums lielākoties strādā ar vienkrāsainiem trikotāžas materiāliem, kurus ziedo uzṇēmus Otrā Elpa. Tomēr paklāju dizaina attīstīšanai tiek izmēǵinātas dažādas tehnologijas un lietoti dažādi materiāli, līdz ar to izgatavošanā izmanto arī trikotāžas izstrādājumu ražotāja SIA ZIB drānu atgriezumus, papildus izmanto arī mežǵīṇu drānu atgriezumus no Latvijas korsešḡērbu izgatavošanas uzṇēmumiem New Rosme un LAUMA Lingerie. Jauna dizaina izstrādē tiek izmēgināta arī uzkārsta drāna - flīss.

Modes dizaineres Annas Aizsilnieces (Ingrīda Zābere) modes projekts RECYCLED.LV veltīts lietu pārstrādei, pārveidojot lietotus apgèerbus jaunos izstrādājumos. Projekta pirmās modes kolekcijas bija Cukurs un $S a \bar{l}$, kuras māksliniece radīja kopā ar modes dizaineri Ināru Gauju. Tie bija mēǵinājumi veidot lietoto apgēēbu modi (21). Jaunā dizainā lielākoties tiek pārstrādātas vilnas, kokvilnas un poliestera drānas. Dizainere veido jaunus izstrādājumus, pāršujot lietotus sieviešu un vīriešu kreklus un žaketes. Viens no RECYCLED.LV kolekcijas Cita Klasika izstrādājumiem parādīts 10. attēlā, kur blūze šūta no 4 krekliem, savukārt svārku darināšanai izmantoti 6 pārstrādāti krekli (22).

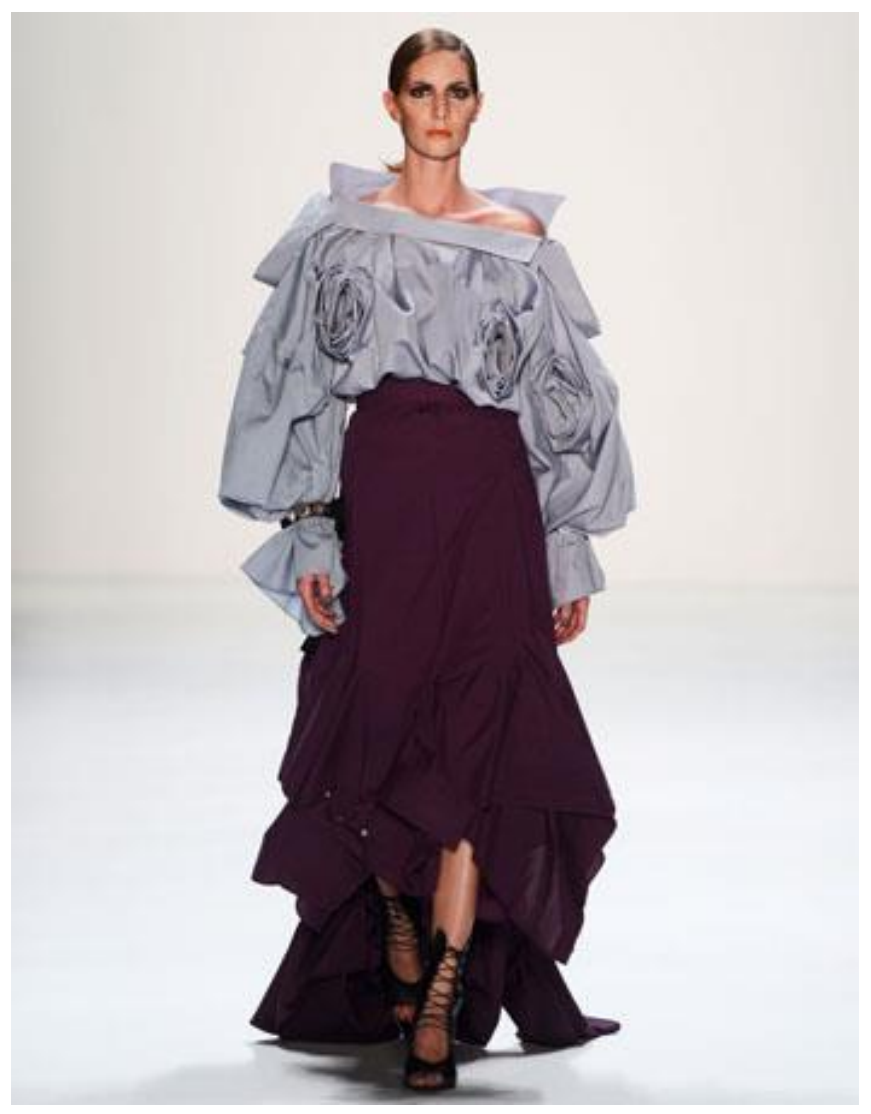

10. att. RECYCLED.LV kolekcijas Cita Klasika modelis (22).

Kopš 2012. gada Latvijā ir atvērts viens no pasaulē visplašāk pazīstamajiem zemo cenu apgèēbu zīmoliem $H \& M$ jeb Hennes \& Mauritz. H\&M pirmsākumi ir meklējami 1947. g., kad Zviedrijas pilsētā Vāsteras tika atvērts apgēerbu veikals Hennes. Šobrīd $H \& M$ zīmola veikali ir pieejami 57 pasaules valstīs un kopā to ir vairāk nekā 3600 (23).

Savu reciklēšanas programmu $H \& M$ CONSCIOUS uzsāka 2013. g. februārī. Programmas ietvaros $H \& M$ piedāvā klientiem veikalos nodot lietotās tekstīlijas. Jau 2014. g. zīmols izlaida savu pirmo reciklētā denima auduma džinsu kolekciju. Katrā izstrādājumā ir $20 \%$ reciklētas kokvilnas (24).

Arī Latvijas $H \& M$ veikalos ir iespējams nodot nevajadzīgo apǵērbu un citus tekstilizstrādājumus. Viss nodotais apǵērbs tiek vai nu ziedots labdarībai, vai reciklēts lupatās, pārstrādāts jaunos izstrādājumos vai enerǵijā.

Nododot tekstilizstrādājumus $H \& M$ veikalos, klientiem tiek izsniegts $15 \%$ atlaižu kupons (11. attēls) vienam pirkumam.

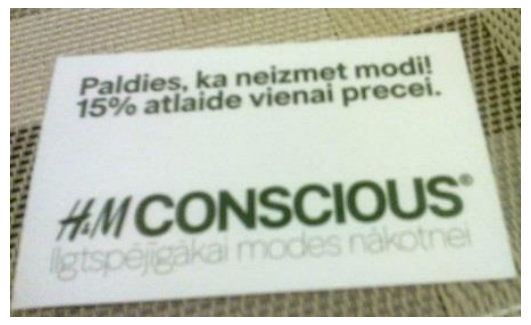

11. att. $H \& M$ atlaižu kupons nododot tekstilizstrādājumus. 


\section{LATVIJAS TEKSTILATKRITUMU UTILIZĀCIJAS UN RECIKLĒŠANAS IESPĒJAS}

Uzñēmums UAB Antriteksa in Lietuvā dibināts tekstilatkritumu šksirošanas, pārstrādes un tirdzniecības uzṇēmums. Tas atrodas Alītā, Naujoji gatvē 132 B, un tas strādā jau 15 gadus. Šobrīd Antriteksa ir nodarbināti 48 cilvēki. Antriteksa galvenokārt pilda starpnieka lomu, savācot vai iepērkot atkritumus no tekstilizstrādājumu ražotājiem un pārdodot tos tekstiliju pārstrādes uzṇēmumiem (25).

Uzņēmumā tekstilatkritumus šķiro pēc šķiedru sastāva, presē ķīpās (12. attēls) un nogādā tekstilmateriālu pārstrādes uzṇēmumiem Eiropā un arī citur pasaulē. Tiek vākti un pārstrādāti dažāda šksiedru sastāva tekstilmateriāli, tomēr tīršksiedru atkritumi ir visizdevīgākie, jo tos ir vieglāk pārstrādāt un tirgus cena tiem ir augstāka.

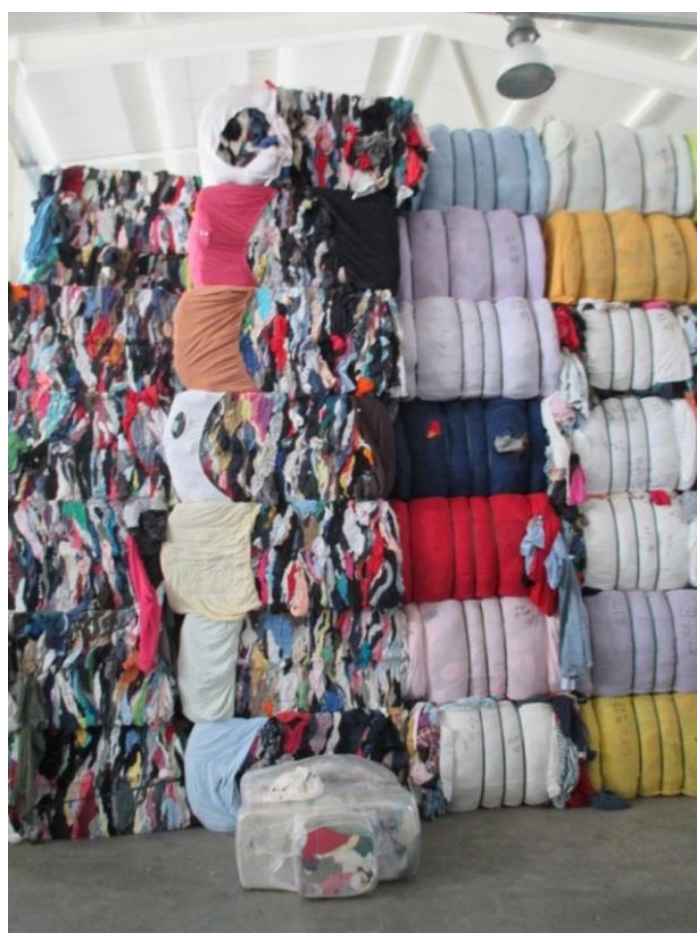

12. att. UAB Antriteksa šķirotie tekstiliju atkritumi.

Ražošanas tekstilatkritumu savākšanai uzñēmums organizē savu transportu. Tomēr atkritumu apjomam jābūt lielam, tāpēc sadarbības uzṇēmumiem jāparedz tekstilatkritumu uzkrāšanas noliktava. Ieteicams, lai tajā būtu tekstilatkritumu prese materiālu sapresēšanai ķīpās, to ērtākai uzglabāšanai un transportēšanai.

Lai arī atkritumi maksā naudu, tomēr Antriteksa nepiedāvā atlīdzību par tekstilatkritumiem. Galvenais Antriteksa arguments ir atkritumu apsaimniekošanas lielās izmaksas. Tā vietā Antriteksa piedāvā bezmaksas tekstilatkritumu izvešanu un apsaimniekošanu. Lai Antriteksa būtu gatavs maksāt par tekstilatkritumiem, uzṇēmumā, kurš vēlas tos pārdot, nepieciešams veikt to sākotnējo škirošanu: tekstilatkritumiem jābūt tīriem, sausiem, bez piegriešanas papīra un plēves, kārtīgi iepakotiem (presētiem), uz ķīpām jānorāda materiāla sastāvs (vienā ķīpā viena veida materiāls), kura ražošanas procesa laikā radušies atkritumi, kādā laika periodā daudzums savākts nedēḷas vai mēneša laikā.
Tekstilatkritumu cena var būt dažāda, lielākoties to nosaka pārrunu cel̦ā. Piemēram, 2015. gada aprīlī uzñēmums no kāda virsǵērbu ražotāja iepirka $100 \%$ poliestera siltās starpoderes (sintepons) atgriezumus par 200 EUR tonnā.

Šobrīd lielu daḷu uzṇēmuma peḷnas veido industriālās lupatas. Tās griež gan no ražošanas atgājām, gan no lietotajiem apǵērbiem. Tiek piedāvāti 17 dažādi lupatu veidi, kurus vēl iedala pēc dažādiem materiālu raksturlielumiem. Viens no svarīgākajiem industriālo lupatu parametriem ir ūdens absorbēšanas spēja. Šīm lupatām lieto tikai kokvilnas materiālus un maksimāli piel̦aujamais cita veida šķiedru piejaukums ir $5 \%$. Uzņēmums pieņem, šķiro un pārstrādā piln̄̄gi visus materiālus, arī atlikumus, kas paliek pēc lietotā apgeērba sagriešanas industriālajās lupatās - pogas, rāvējslēdzējus u.c. furnitūru. Tos transportē uz Indiju, kur tos atkārtoti izmanto.

Uzṇēmuma darbības pirmsākumos, sadarbojoties ar Amerikas Savienotajām Valstīm (ASV), aktuāla bija kokvilnas tekstilatkritumu pārstrāde naudas papīrā. Pamazām šāda veida kokvilnas pārstrāde sāk atgriezties un naudas papīu no reciklētā tekstila ražo Nīderlandē un Vācijā.

Šobrīd vienīgie Antriteksa darbības virzieni ir škirošana un industriālās lupatas, tomēr uzṇēmums plāno attīstīties un iegādāties iekārtas, ar kurām var ražot poliamīda aglomerātu. Lielākais $100 \%$ poliamīda šķiedru materiāla pasūtītājs un aglomerātu ražotājs ir Vācija.

UAB Antriteksa ir ieinteresēts sadarboties ar Latvijas tekstilizstrādājumu ražošanas uzņēmumiem. Pašreiz sadarbība izveidota tikai ar mājas tekstilražošanas uzņēmumu SIA Mežroze. No Latvijas uzṇēmuma savāktie tekstilatkritumu apjomi nav lieli, tomēr Mežroze ir viens no lielākajiem kokvilnas izstrādājumu ražotājiem Latvijā.

Latvijā pieejama arī tekstilizstrādājumu utilizācija sadedzinot. To veic Maltas dzīvokḷu - komunālās saimniecības uzñemums. Tur tekstilatkritumus dedzina siltumenergijas ieguvei.

Uzñēmuma sniegtā informācija liecina, ka vidēji tiek sadedzināts apmēram $5 \mathrm{t}$ tekstilatkritumu mēnesī, tomēr uzņēmums ir ieinteresēts utilizēt lielāku tekstilmateriālu apjomu.

Tekstilatkritumu nodošanas tarifs par $1 \mathrm{t}$ atkritumu ir 14,23 EUR bez pievienotās vērtības nodokḷa (PVN). Tekstilatkritumu transportēšanu līdz uzṇēmumam organizē paši atkritumu radītāji. Maltas dzīvokļu - komunālās saimniecības uzņēmums pieņem tekstilatkritumus gan no privātpersonām, gan no juridiskām personām.

\section{IETEIKUMI TEKSTILATKRITUMU RECIKLĒŠANAI UN UTILIZĒŠANAI LATVIJĀ}

N̦emot vērā to, ka Latvijas “Atkritumu apsaimniekošanas valsts plāns 2013.-2020. gadam” neparedz atsevišḳu tekstilatkritumu apsaimniekošanu, bet gan klasificē tos kā sadzīves atkritumus, visi tekstilatkritumi tiks apglabāti atkritumu poligonos (6). Lai uzlabotu š̄i brīža situāciju un tekstilatkritumi nenonāktu atkritumu poligonos, radot kaitējumu apkārtējai videi, nepieciešams informēt patērētājus un ražotājus par efektīvākiem un izdevīgākiem tekstilatkritumu apsaimniekošanas veidiem. 


\section{A. Ieteikumi tekstilpreču patērētājiem}

Katru gadu apgēerbu un tekstilizstrādājumu cena samazinās, bet cilvēka un vides veselības izmaksas strauji palielinās. Ražotāji, liekot patērētājiem domāt, ka viṇi ir spējīgi iegādāties daudz, rada neatgriezenisku kaitējumu videi - veidojas tonnām atkritumu, kas krājas poligonos, piesārṇo gaisu, augsni un ūdeni. Patērētāji ir raduši pie straujas modes tendenču maiņas un tā ir viena no vislielākajām problēmām vides aizsardzības jomā. Lietas tiek iegādātas par zemākām cenām, attiecīgi arī to kvalitāte ir zemāka, tādēḷ tās ātri nonāk atkritumos.

Tekstilatkritumu apjoms Latvijā, salīdzinot ar citiem atkritumu veidiem, kas rodas Latvijā, nav pats lielākais. Tomēr vides situācijas uzlabošanai svarīgi pareizi apsaimniekot visus atkritumu veidus.

Latvijā patērēto tekstiliju pārstrāde lielākoties norit, pateicoties labdarības organizācijām, kas apgādā ar ziedotiem tekstilizstrādājumiem maznodrošinātos, bērnu namus, cietumus, patversmes utt. Tekstilatkritumus Latvijā pārstrādā arī pārdodot. Lietotos tekstilizstrādājumus var nodot atkritumu šksirošanas punktos, ziedot labdarības organizācijām, kā arī pārdod internetā vai komisijas veikalos.

Latvijā ir pieejami 10 tekstilatkritumu šķirošanas punkti (13. att.). Nodotos tekstilatkritumus apsaimnieko (26): SIA Viduskurzemes AAO, SIA APSAIMNIEKO SABIEDRİBA „PIEJŪRA, SIA Dīlers, SIA EKO LATGALE,; SIA DOVA,; SIA ALAAS.

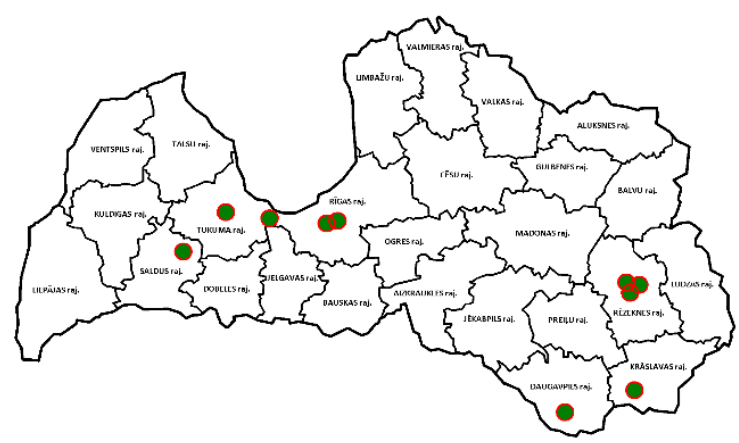

13. att. Tekstilatkritumu šksirošanas punktu atrašanās vietas (26).

Ziedojot vai pārdodot lietotos tekstilizstrādājumus, jāpievērš uzmanība to vispārējam stāvoklim. Ja lietas ir pārāk nolietotas, netīras, saplēstas vai kādā citā veidā bojātas, tās labāk nogādāt tekstilatkritumu šksirošanas punktos.

\section{B. Ieteikumi tekstilizstrādājumu ražotājiem}

Par ttekstilatkritumiem, kas rodas ražošanas procesā, ražotājs ir atbildīgs pats, un par šo atkritumu apsaimniekošanu ir jāmaksā. Atkarībā no uzņēmuma ražošanas apjoma, veidojas arī tekstilatkritumu apjoms. Maksa par šo atkritumu apsaimniekošanu ir augsta. Alternatīva atkritumu apsaimniekošanas izmaksu samazināšanai ir sadarbība ar atkritumu reciklēšanas vai utilizēšanas uzṇēmumiem. Šāda sadarbība ir ne tikai ekonomiski izdevīga, bet arī dabai draudzīga.

Latvijā joprojām nav tekstiliju reciklēšanas uzṇēmumu un Latvijas tekstilrūpniecības uzṇēmumiem jāizmanto iespējas sadarboties ar daudzajiem reciklēšanas uzņēmumiem citur Eiropā. Tuvākie sadarbības partneri atrodami Lietuvā (UAB Antriteksa, (25)) un Igaunijā (AS Toom textile, kurš atrodas
Igaunijā, Vīlande, Leola iela 49), bet Latvijā tekstilatkritumus iespējams utilizēt sadedzināšanas uzņēmumā SIA Maltas dzīvoklı - komunālās saimniecības uzņēmums, kurš atrodas Latvijā, Maltā, Skolas ielā 13.

Tekstilatkritumi pirms to nosūtīšanas uz pārstrādes uzñēmumiem, ir jāsagatavo, kā to prasa pārstrādātājs. Tiem jābūt tīriem, sausiem, iepakotiem, bez piegriešanas papīra un plēves. Tekstilatkritumu apsaimniekošanas etapi:

1. Noskaidrot tekstilrūpniecības uzñēmuma faktiskos mēneša un gada izdevumus par atkritumu apsaimniekošanu;

2. Izvērtēt tekstilatkritumus pēc to šķiedru sastāva;

3. Noskaidrot alternatīvas esošajai tekstilatkritumu apsaimniekošanas sistēmai uzñēmumā. Viens no variantiem ir tekstilatkritumu nodošana vai pārdošana kādam no tekstilatkritumu reciklēšanas uzṇēmumiem, otrs variants - tekstilatkritumu nodošana utilizēšanai atkritumu sadedzināšanas uzṇēmumam;

4. Noskaidrot alternatīvos atkritumu apsaimniekošanas sniedzējus un to sadarbības noteikumus.

5. Aprēķināt tekstilatkritumu apsaimniekošanas izmaksas visiem alternatīvajiem apsaimniekošanas variantiem.

Pētījuma rezultātā tika izstrādāts algoritms tekstilatkritumu racionālas apsaimniekošanas procesam tekstilražošanas uzñēmumā (14. att.).

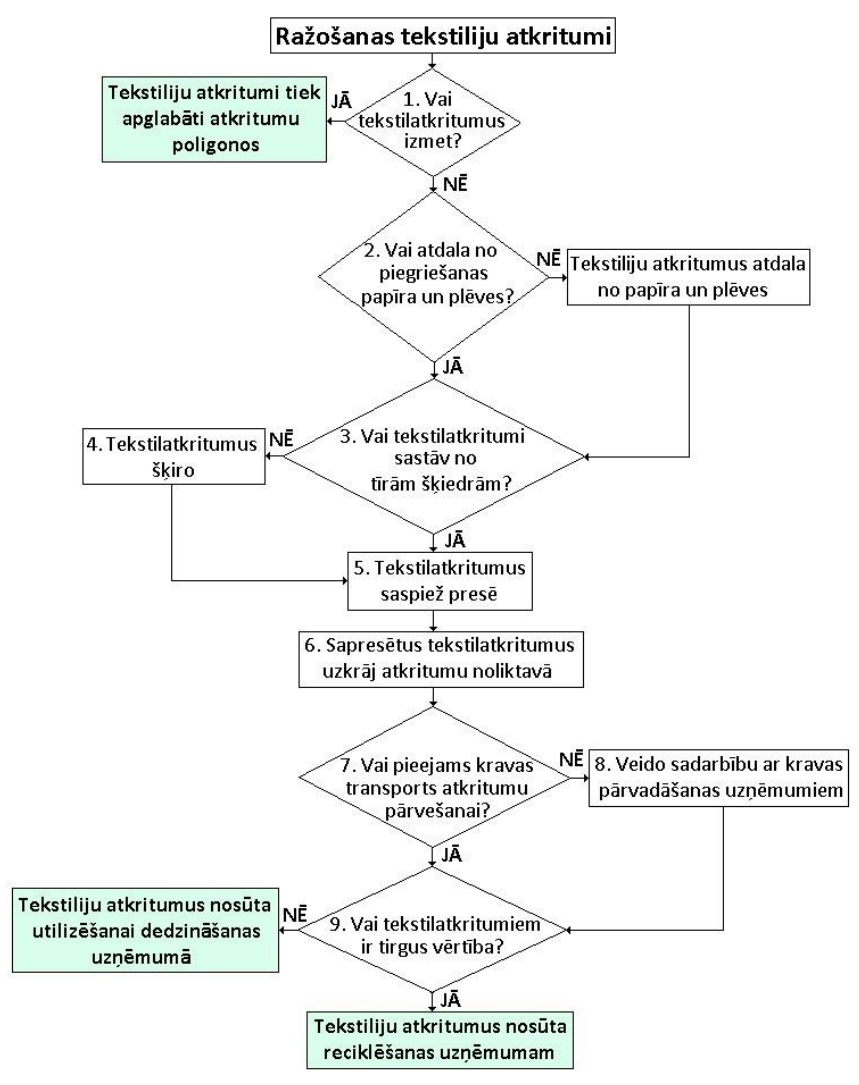

14. att. Tekstilatkritumu apsaimniekošanas ieteikumu algoritms. 
TEKSTILATKRITUMU APSAIMNIEKOŠANAS ALGORITMA (14. ATT.) SKAIDROJUMS

\begin{tabular}{|c|c|}
\hline 1 & $\begin{array}{l}\text { Tekstilatkritumi tiek izmesti sadzìves atkritumu konteineros. } \\
\text { Atkritumu apsaimniekošanas izmaksas vidēji 6,00 EUR bez PVN par } \\
\mathrm{m}^{3} \text {. }\end{array}$ \\
\hline 2 & $\begin{array}{l}\text { Noskaidro informāciju vai papīrs un plēve (ko lieto detaļu } \\
\text { piegriešanas procesā) } \\
\text { tekstilatkritumiem. }\end{array}$ \\
\hline 3 & $\begin{array}{l}\text { Noskaidro informāciju par pārstrādes procesā } \\
\text { tekstilmateriāla sastāvā esošo škiedru daudzveidību }\end{array}$ \\
\hline 4 & $\begin{array}{l}\text { Tekstilatkritumus šksiro pēc to šķiedru sastāva, nodalot vērtīgos } \\
\text { atkritumus: poliamīds, kokvilna u.c. }\end{array}$ \\
\hline 5 & $\begin{array}{l}\text { Nepieciešama tekstilatkritumu presēšanas iekārta. Iekārtas aptuvenā } \\
\text { cena ir no 2000-28000 EUR. }\end{array}$ \\
\hline 6 & $\begin{array}{l}\text { Tekstilatkritumu uzglabāšanas noliktavai jāatrodas sausā, tīrā, labi } \\
\text { ventilējamā vietā ar vieglu pieklıvi. Mitrums un temperatūra nedrīkst } \\
\text { ietekmēt tekstilatkritumu stāvokli to uzglabāšanas laikā. Jāveic } \\
\text { noliktavas izveides un/vai uzturēšanas izdevumu aprēksini. }\end{array}$ \\
\hline 7 & $\begin{array}{l}\text { Vai uzñēmumam ir pieejams kravas transports, kura celtspēja ir sākot } \\
\text { no } 1 \mathrm{t} \text { (minimālais piegādes apjoms tuvākajam tekstilatkritumu } \\
\text { reciklētājam Lietuvā), un vai šis transports ir spējīgs veikt attālumu } \\
200 \mathrm{~km} \text { un vairāk. }\end{array}$ \\
\hline 8 & $\begin{array}{l}\text { Izmaksas atkarīgas no pārvadātāja uzstādītajiem tarifiem. 2015. gada } \\
\text { maijā tarifs par } 1 \mathrm{~km} \text { ir } 0,40-1,30 \text { EUR un tarifs par stundu ir 5,00- } \\
\text { 40,00 EUR. Cenu veido transportlīdzekḷa veids, tā celtspēja, kravas } \\
\text { saturs un attālums. }\end{array}$ \\
\hline 9 & Vai tekstilatkritumi ir viegli reciklējami un tiem ir tirgus vērtība? \\
\hline
\end{tabular}

Lai tekstilatkritumu sagatavošanas process neradītu nepārdomātus izdevumus, uzṇēmumā jāizveido to uzglabāšanas noliktava, līdz tos transportē uz pārstrādes uzņēmumu. Jāaprēķina atkritumu noliktavas izveides izmaksas.

Tekstilatkritumu daudzuma aprēķins: tekstilatkritumu apsaimniekošanas izmaksu aprēķinam jāzin - cik tekstilatkritumu rodas dienas, mēneša vai gada laikā. Tekstilatkritumu daudzumu kilogramos nosaka pēc sagaidāmā materiālu daudzuma ražošanas pasūtījumā, drānu klājuma garuma, drānu klājumu skaita un materiālu zuduma (\%). Kopējo tekstilatkritumu daudzumu var aprēķināt, reizinot darba dienas, mēneša vai gada ražošanas apjomu ar vidējo tekstilatkritumu daudzumu uz vienu izstrādājumu.

Tekstilatkritumu noliktava un presēšanas iekārta: tekstilatkritumu rašanās daudzumu dienā, mēnesī un gadā nosaka atkarībā no uzņēmuma ražošanas jaudas. Atkritumu uzkrāšanas noliktavu var paredzēt gan uzṇēmuma telpās, gan ārpus tā. Sapresēti tekstilatkritumi aizņem mazāk vietas, un tos ir vieglāk pārvaldīt, tādēl svarīgi iegādāties atkritumu presēšanas iekārtu, kas sapresē ķīpās. Vidējā tekstilatkritumu presēšanas iekārtas cena ir 3000 EUR; tas ir ilgtermiṇa ieguldījums.

Elektroenergijas patēriņš: aprēķinot izmaksas, tekstilatkritumu noliktavas izveidei, jānosaka presēšanas iekārtas elektroenerǵijas patēriņš, kas atkarīgs no iekārtas ražošanas ciklu skaita periodā, tās jaudas un elektroenerǵijas tarifa. Iekārtas nolietojumu nosaka saskaņā ar uzņēmumā pieņemtajām pamatlīdzekḷu nolietojuma aprēķina metodēm.

Darbinieku darba algas piemaksa: darbinieku darba algas piemaksas par tekstilmateriālu presēšanas iekārtu apkalpošanu aprēķina, reizinot stundas tarifa likmi ar presēšanas iekārtas apkalpošanas laiku un ar darba devēja sociālo maksājumu, vai arī nosaka pēc uzṇēmumā pieņemtās piemaksu aprēķināšanas sistēmas.

Tekstilatkritumu transportēšanas izmaksas: pēc kopējo aprēķinu veikšanas, tekstilatkritumu noliktavas izveidei, nepieciešams aprēḳināt tekstilatkritumu transportēšanas izmaksas līdz reciklēšanas vai utilizēšanas uzñēmumam.

Tekstilatkritumu utilizācijas izmaksas: ja tekstilatkritumi tiek utilizēti dedzināšanas uzñēmumos, tad utilizēšanas izmaksu plānošanā jāparedz tekstilatkritumu likvidācijas izmaksas. Tarifs par ttekstilatkritumu utilizāciju dedzinot, tiek piemērots par $1 \mathrm{t}$ tekstilatkritumu. SIA „Maltas dzīvokḷu - komunālās saimniecības uzn̄ēmumā” tarifs par tekstilatkritumu utilizāciju ir 14,23 EUR bez pievienotās vērtības nodokḷa.

Tekstilizstrādājumu ražošanas uzņēmumi, kuri tekstilatkritumus šķiro pēc to veidiem un šķiedru sastāva, par savu atkritumu reciklēšanu var saņemt arī peļnu. Tekstilatkritumu reciklēšanas uzñēmumi, atkarībā no to specializācijas (pārstrādā visu veidu tekstilatkritumus vai specializējas kāda konkrēta materiāla pārstrādē), ir ieinteresēti iegūt tekstilatkritumus, nemaksājot par tiem. Tekstilatkritumi, it sevišksi tie, kuri sastāv no jebkādas tīras jeb 100\% šķiedras, ir izejmateriāli, kuriem ir tirgus vērtība. Teksilatkritumu cena var būt dažāda, tā tiek noteikta pārrunu cel̦ā. Ekonomiski visizdevīgākie materiāli ir tie, kas ražoti no sintētiskajām šksiedrām - poliesters, poliamīds u.c., jo tos var pilnībā reciklēt un atkal atgriezt ražošanā kā izejvielas. Arī par dabīgo šķiedru tekstilmateriāliem (vilna, kokvilna u.c.) iespējams iegūt samaksu. Dabīgo šksiedru tekstilmateriālus pārstrādā neausto drānu materiālos. Bieži tekstilatkritumu reciklēšanas uzṇēmumi par tekstilatkritumiem nepiedāvā samaksu, tomēr tekstilražotājiem ir jāzina, ka atkritumiem šodien ir vērā ņemama tirgus vērtība, jo tie ir lietderīgs resurss.

\section{LITERATŪRAS SARAKSTS}

1. Krūzs, K. Dabas un otrreizējo resursu izmantošana. Rīga: Izglītības soḷi, 2003. 131. 1pp. ISBN 9984-712-42-7

2. Report of the United Nations conference on environment and deveopment. Rio declaration on environment and development [online]. Vol. I.United Nations General Assembly: Rio de Janeiro, 1992. A/CONF.151/26 [viewed 26 March 2015]. Available from: http://www.un.org/documents/ga/conf151/aconf15126-1annex1.htm

3. Directive 2008/98/EC on waste (Waste Framework Directive) [online]. [viewed 12 December 2014] Available from: http://ec.europa.eu/environment/waste/framework/index.htm

4. Eiropas Parlamenta un Padomes direktīva. Par atkritumiem un dažu direktīvu atcelšanu. Eiropas savien̄̄bas Oficiālais Vēstnesis, 22.11.2008. 30 lpp. 2008/98/EEK

5. Waste excluding major mineral wastes [online]. [viewed 26 March 2015]. Available http://appsso.eurostat.ec.europa.eu/nui/submitViewTableAction.do

6. Atkritumu apsaimniekošanas valsts plāns 2013.-2020. gadam. Vides aizsardzības un Reǵionālās attīstības Ministrija: Rīga, 2012

7. Ministru kabineta rīkojums Nr.860. Par atkritumu apsaimniekošānas valsts plānu 2006.-2012. Gadam [tiešsaite]. Rīga, 2005, [skatīts 2015.g. 7. maijs]. Pieejams: http://www.likumi.lv/doc.php?id=124880

8. Alekscic, D. Municipal waste management in Latvia [online]. Regional Enviromenta Center, 2013, [viewed: 27 February 2015] Available from: http://www.eea.europa.eu/publications/managing-municipal-solidwaste/latvia-municipal-waste-management

9. Vides politikas pamatnostādnes 2009.-2015. gadam (Informatīvā dala). Pielikums Ministru kabineta rīkojumam Nr.517. Vides Ministrija: Rīga,2009. "LV", 122 (4108), 04.08.2009

10. Cakars, I. Pārskats par atkritumu izgāstuvēm un poligoniem Latvijā 2010.gadā [tiešsaite]. LVĢMC Ķīmisko vielu un bīstamo atkritumu $\begin{array}{lllll}\text { nodala } & \text { 2015.g. } 7.7 \text { maijs]. }\end{array}$ https://www.meteo.lv/fs/CKFinderJava/userfiles/files/Vide/Atkritumi/sta tistika/Parskats\%20par\%20atkritumu\%20izgaztuvem\%20un\%20poligon iem\%20Latvija\%202010.\%20gada.pdf

11. Uzņēmējdarbības rādītāji rūpniecībā 2013. gadā (provizoriski dati) [tiešsaite]. Uzṇēmumu finanšu un strukturālās statistikas daḷa, Centrālā statistikas pārvalde. RUG0001[skatīts 2015.g. 17. maijs]. Pieejams: 
http://data.csb.gov.lv/pxweb/lv/rupnbuvn/rupnbuvn__ikgad__rupn/RU0 001_euro.px/table/tableViewLayout1/?rxid=cdcb978c-22b0-416a-aaccaa650d3e2ce0

12. Search: textile recycling [online]. [viewed 13 February 2015] Available from: http://www.europages.co.uk/companies/textile\%20recycling.html

13. Fletcher, K. Sustainable fashion \& textiles. Design Journeys. London: Earthscan, 2008. 239. pp. ISBN: 978-1-84407-481-5.

14. Training programme "Cleaner Production in Latvian Industries"[online]. [viewed 31 June 2015]. Available from: http://www.varam.gov.lv/eng/dokumenti/politikas_planosanas_dokumen ti/?doc $=3297$

15. How is cotton recycled?[online]. [viewed 27 March 2015]. Available from: http://www.living-bag.com/how_cotton.html

16. Our Story [online]. [viewed 27 March 2015]. Available from: http://www.in2green.com/pages/our-story

17. Brizga, J., Teibe, I., Pusvilka, A., Ozola, L., Jansons, M. Bez atkritumiem. Vadlīnijas nevalstisko organizāciju kapacitātes stiprināšanai. Biedrība "homo ecos:": Rīga, 2014, 52 lappuses. ISBN 978-9934-14-183-6

18. What is energy from waste (EfW)? [online]. [viewed: 28 May 2015] Available from: http://www.arc21.org.uk/opencontent/?itemid=27\&section=Residual+W aste+Project

19. Sociālā uzṇēmuma „Otrā Elpa” 2014. gada pārskats. Uzṇēmuma informācija

20. Mežğinun paklāji - “LUDE” [tiešsaite]. Fold, 2014 [skatīts 2015.g. 4.febr.] Pieejams: http://www.fold.lv/2014/04/mezginu-paklaji-lude/

21. Krastinšs, A. "RECYCLED.LV": Geniālais tiek radīts sirds līmeñ̄ [tiešsaite]. 2014 [skatīts 2015.g. 4.febr.]. Pieejams: http://www.7guruvesture.lv/petnica/recycled-lv-genialais-tiek-raditssirds-limeni

22. Kolekcijas: Cita klasika [tiešsaite]. [skatīts 2015.g. 4. Febr.]. Pieejams: http://recycled.lv/index.php?lang=lv\&remote=J\&id=r34\&item=295

23. About H\&M. History [online]. [viewed 22 May 2015]. Available from: http://about.hm.com/en/About/facts-about-hm/people-andhistory/history.html

24. H\&M makes jeans from recycled cotton [online]. [viewed 22 May 2015]. Available from: http://www.theguardian.com/sustainable-business/hmpartner-zone/h-and-m-jeans-recycled-cotton

25. Antriteksa, UAB [онлайн]. [просмотр 2015.г. 13. марта] Доступный: http://imones.lrytas.lt/ru/antriteksa-uab

26. Tekstilmateriāli [tiešsaite]. [Skatīts: 2015.g. 17. aprīlis]. Pieejams: http://www.atkritumi.lv/lv/skirosana/tekstilmateriali/

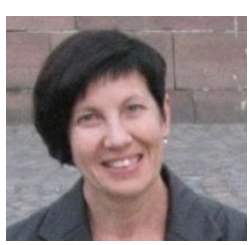

Inese Ziemele holds the Dr. sc. ing. degree. The fields of her studies were optimization of sewing parameters and selective methods of sewing machines for assurance of guaranteed quality in the garment production layout.

From 1998 to 2007, she was a senior technologist in LLC Solutions, Riga, Latvia; and since 2007 she is a researcher and Assistant Professor at the Institute of Design Technologies, Faculty of Materials Science and Applied Chemistry, Riga Technical University.

Address: Institute of Design Technologies, Riga Technical University, Kipsalas Str. 6, Riga, Latvia, LV-1048.

E-mail: inese.ziemele@rtu.lv

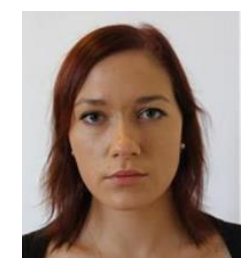

Ilze Kovaļevska received Professional Bachelor degree in Clothing and Textile Technology in 2015 from Riga Technical University.

E-mail: kovalevska.ilze@inbox.lv

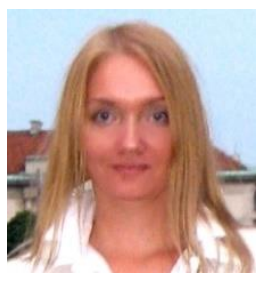

Dana Belakova, $\mathrm{PhD}$, is a researcher (2003) and currently she is Assistant Professor at the Institute of Design Technologies, Faculty of Materials Science and Applied Chemistry, Riga Technical University. The field of her studies is designing of work methods, estimation of time standards, improving the working time estimation in sewing companies.

Address: Institute of Design Technologies, Riga Technical University, Kipsalas Str. 6, Riga, LV1048, Latvia. E-mail: dana.belakova@ rtu.lv

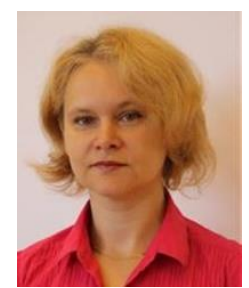

Iveta Abele received Mg. sc. ing. degree in Clothing and Textile Technology and the qualification of an engineer in Clothing and Textile Production in 1998 from Riga Technical University.

She is currently a Doctoral student at Riga Technical University. Since 2013 she is a supervisor of studies at the Institute of Design Technologies, Faculty of Materials Science and Applied Chemistry, Riga Technical University.

Since 2010 she is a Researcher at the Institute of Design Technologies, Faculty of Materials Science and Applied Chemistry, Riga Technical University.

Address: Institute of Design Technologies, Riga Technical University, Kipsalas Str. 6, Riga, LV-1048, Latvia.

E-mail: iveta.abele@rtu.lv

\section{Inese Ziemele, Ilze Koval̦evska, Dana Bel̦akova, Iveta Abele. Utilization and recycling of textile waste}

Among the other everyday goods, volume of textile waste is growing rapidly. Moreover, lot of waste comes from Latvian textile production enterprises. Management of textile waste is still not established in Latvia and there is no national system for that. Therefore, potentially useful textile materials are disposed in landfills. One of the main principles of reduction of landfills and $\mathrm{CO}_{2}$ emissions and increase of the amount of textile waste recycled is "Polluter pays for the pollution." That necessitates the polluter to look for other waste management techniques instead of disposal and burning. Currently, it is topical to develop recommendations for proper management of textile waste in order to reduce waste management costs and save natural resources. Taking into account the fact that the Latvian "National Waste Management Plan 2013-2020" does not provide a separate textile waste management, but classifies them as municipal waste, the largest quantity of textiles may end up in landfills. This research concludes that there is still no textile recycling companies in Latvia and Latvian textile companies have to cooperate with recycling enterprises in Europe. Nearest partners are located in Lithuania (UAB Antriteksa) and Estonia (Toom textile, Ltd.). The second and less environment friendly way of Latvian textile companies to get rid of textile waste is delivering them for burning to the company Maltas apartments - public utility, located in Latvia, Malta. Before textile waste is sent to a recycling company, they should be prepared as required by the recycling company. The waste must be clean, dry, packaged without cutting paper and film. Within this research textile waste management stages are identified and a rational management recommendation algorithm is designed. 
Инесе Зиемеле, Илзе Ковалевска, Дана Белякова, Ивета Абеле. Утилизация и переработка текстильных отходов

Среди объемов отходов других товаров повседневного спроса быстро растут также и объемы отходов текстиля. Кроме того, немало отходов образуются на текстильных предприятиях Латвии. К сожалению, в Латвии до сих пор не создана единая национальная система утилизации текстильных отходов, и потенциально полезные материалы попадают на свалки. Одним из основных принципов сокращения выбросов СО2 на полигонах и увеличения повторно использованных текстильных отходов является принцип «загрязнитель платит за загрязнение». Это предполагает поиск других методов утилизации отходов, как закапывание и сжигание, за что латвийские граждане и предприятия платят с каждым годом больше. В настоящее время, актуальной стала разработка рекомендаций по правильной сортировке и утилизации текстильных отходов в целях сокращения расходов по управлению отходами и сохранения природных ресурсов. Учитывая тот факт, что в латвийском «Национальном плане утилизации отходов в $2013-2020$ гг.» не предусмотрено отдельной программы утилизации текстильных отходов, они классифицированы как бытовые отходы, наибольшее количество из текстиля может в конечном итоге попасть на свалки. Исследование показало, что в Латвии до сих пор нет компаний по вторичной переработке текстиля, и латвийские текстильные компании должны использовать возможности сотрудничать со многими предприятиями по переработке в других странах Европы. Ближайшие партнеры находятся в Литве (UAB "Antriteksa") и Эстонии ("Toom textile"). Второй, менее экологически чистый способ избавления от отходов латвийских текстильных предприятий - поставлять их предприятию «Мальтийские коммунальные квартиры», расположенному в Латвии, Мальте для сжигания. Прежде чем отправить текстильные отходы на перерабатывающие предприятия, их нужно подготовить. Они должны быть чистыми, сухими, упакованными без закроечной бумаги и пленки. В исследовании выявлены этапы переработки текстильных отходов и разработан алгоритм рационального управления отходами. 